\title{
Lowering the Sultan's Flag: Sovereignty and Decolonization in Coastal Kenya
}

\author{
JAMES R. BRENNAN \\ University of Illinois at Urbana-Champaign and SOAS, University of London
}

On 17 December 1961, Ronald Ngala faced an audience of some five hundred supporters in Malindi, a town on the East African coast of the Indian Ocean. The crowd had come to watch Ngala lower the flag that symbolized colonial rule along the coast. This was not the Union flag of Great Britain, but the red flag of the Sultan of Zanzibar. It flew over a number of towns located along the ten-mile coastal strip "Protectorate" of what was then Kenya Colony and Protectorate. The flag symbolized this latter legal distinction, representing the sovereignty that the Sultan of Zanzibar retained over the coastal strip of Kenya after leasing its administration to Britain in a treaty signed in 1895. The flag's lowering was an act of political theatre-Ngala's supporters had hastily arranged the flag and flagpole, while the Sultan's real flag flew over the Malindi courts office nearby. The crowd celebrated its lowering with loud and wild cheers. Anxious onlookers later complained that Ngala had performed an act of treason. ${ }^{1}$ In Zanzibar, tense with the specter of racial violence, local press expressed outrage at this insult to the Sultan. ${ }^{2}$

The ceremony celebrated the just-released findings of the Robertson Commission, which recommended that the coastal strip be detached from the Sultan of Zanzibar's nominal sovereignty and legally joined to mainland Kenya before the country reached independence. This would happen in October 1963,

Acknowledgments: Earlier versions of this article were presented at University of North CarolinaChapel Hill, Johns Hopkins University, and Zentrum für Moderner Orient (ZMO), Berlin. I thank Mohamed Bakari, Sara Berry, Jeffrey Brooks, Andy Eisenberg, Bruce Hall, Kai Kresse, Pier Larson, Lisa Lindsay, Christopher Lee, Hassan Mwakimako, Jeremy Prestholdt, Abdul Sheriff, Farouk Topan, Justin Willis, and four anonymous CSSH reviewers for their comments. I also thank the British Academy for its Small Research Grant (SG-41863) that funded research visits to Kenya in 2006-2007, and Kenya National Archives staff for their invaluable assistance.

${ }_{1}$ Mombasa Times, 18 Oct. 1961, and subsequent letters.

2 Acting British Resident, Zanzibar to Maudling, 20 Dec. 1961, Colonial Office, British National Archives, Kew [hereafter CO] 822/2046/200. An investigation was later launched against Ngala, but no charges were brought. Deputy Governor Kenya to Maudling, 18 Dec. 1961, CO 822/ 2150/178. 
shortly before Kenya's independence. The politics surrounding this 1895 treaty between Britain and the Sultan of Zanzibar stands at the center of a largely forgotten chapter in the history of Africa's decolonization. It was the legal point upon which the mwambao ("coastline" in Swahili) movement seized to argue for autonomy, and even outright independence, from mainland Kenya as East Africa moved towards self-rule. The pursuit of mwambao (c. 1953-1963) was led by Arab and Swahili residents of the Kenyan coast who feared political domination by Africans living along the coast and immigrating from "upcountry.", Mwambao supporters sought to protect a number of privileges - the position of sharia, local elite control over land, staffing of bureaucratic posts, to name a few - that had been secured by, or at least associated with, the Sultan's position as nominal sovereign. Conversely, the lowering of the Sultan's flag symbolized to coastal Africans such as Ronald Ngala the end of a deviously schemed "autonomy," and with it the imminent end of Africans' squatter relationship with absentee Arab landlords, as well as a haughty ulama's domination over local institutions of law and education. It also represented the opening of opportunities for both coastal Africans and African immigrants from upcountry, who were engaged in bitter political competition to gain control over the coast's bureaucratic machinery. The politics of mwambao resembled those of Zanzibar - an Arab and Swahili political movement's attempt to identify with the Sultan to protect a number of privileges resented by Africans. But unlike Zanzibar, where upwards of ten thousand Arabs and Indians were massacred in the islands' political revolution of January 1964, mwambao died a relatively peaceful death as the coast came under formal control from Nairobi. Earlier studies interpreted mwambao as a doomed strategy of coastal elites to protect a set of colonial-era privileges in the face of African nationalism, and portrayed its failure as a disguised blessing that spared the coast from the horrific violence that engulfed Zanzibar. ${ }^{4}$

This article does not seek to refute these arguments. Rather, it proposes to frame mwambao differently, not as a small flash in the regional pan of racial and religious politics, but as part of an extended struggle over the meaning

\footnotetext{
3 The terms "Arab" and "Swahili" raise thorny issues of coastal identity. To abbreviate an interminable debate, the identity of "Arab" in coastal East Africa may indicate ancestral origins in Arabia, but certainly marks a claim to high social status. "Swahili" is predominantly an "etic" term that classifies (however problematically) people who have adopted coastal culture, including not only Swahili language and Islam, but also plausible membership in local lineages. In identifying with coastal culture, "Arab" and "Swahili" categorically differentiate themselves from mainland Africans.

4 A. I. Salim, The Swahili-Speaking Peoples of Kenya's Coast (Nairobi: East African Publishing House, 1973), 220-46; idem., "The Movement for 'Mwambao' or Coast Autonomy in Kenya, 1956-1963," Hadith 2 (1970): 212-28; Richard Stren, Housing the Urban Poor in Africa: Policy, Politics and Bureaucracy in Mombasa (Berkeley: Institute of International Relations, 1978), 74-87; and Hyder Kindy, Life and Politics in Mombasa (Nairobi: East African Publishing House, 1972), 184-91.
} 
of sovereignty. The central position of the 1895 treaty facilitated an unusual volume of discussion about sovereignty, so to some extent the case of mwambao is sui generis. But such profuse popular debate over sovereignty also offers a rich opportunity to place the event within wider contexts - a regional one of ideational continuity along the Swahili coast and Indian Ocean littoral, and a temporal one of major ruptures which accompanied British colonization, decolonization, and the emergence of a post-war international order. I argue that efforts to secure coastal autonomy represent a regionally and historically specific type of sovereignty pursued by mwambao activists not simply to guard political and material privileges, but more broadly to express a language of political legitimacy that still resonates today.

THE IDEA OF SOVEREIGNTY IN INDIAN OCEAN SOCIETIES, ISLAMIC SOCIETIES, AND DECOLONIZING AFRICA

Examining the history of sovereignty in a non-Western context raises methodological questions of comparison and connection. Sovereignty in coastal Kenya can be approached as a regional site where analogies to a possibly universal idea were produced, as well as a colonial site upon which metropolitan notions were imposed and appropriated. But is it first worth asking if there has ever been a stable notion of sovereignty? Studies proposing a stable form and linear history trace its modern gestation in the Augsburgian and Westphalian systems of early modern Europe, where sovereignty refers to the final political authority within a given territorial unit; one is sovereign if one can plausibly deny recognition to any higher authorities. ${ }^{5}$ Among sovereignty's attributes are a ruler's right to determine a given territory's religion (cuius regio, eius religio), the territorial integrity of a singular sovereign's power, and the normative legal equality between sovereigns. Westphalian language anchors typologies of international relations studies on sovereignty, which distinguish between "international legal" sovereignty (mutual recognition between territorial entities with formal juridical independence) and "Westphalian" sovereignty (exclusion of external actors from authority structures within a given territory). ${ }^{6}$ These widely held understandings have recently come under fruitful criticism. Seeking to liberate sovereignty from its Eurocentric teleologies,

5 The authoritative study in this vein remains F. H. Hinsley, Sovereignty (Cambridge: Cambridge University Press, 2d ed., 1986). Also working within a European framework but alive to sovereignty's instability is James J. Sheehan, "The Problem of Sovereignty in European History," American Historical Review 111 (2006): 1-15.

6 These typologies, as well as "domestic" sovereignty (the exercise of control within borders) and "interdependence" sovereignty (the control of borders), are from Steven Krasner's influential Sovereignty: Organized Hypocrisy (Princeton: Princeton University Press, 1999). Krasner admits that "Westphalian" sovereignty relates little to the 1648 Peace of Westphalia, and emerges only in the late eighteenth century; he adopts the term because of its common usage. Ibid., 20. 
Radhika Mongia and Antony Anghie argue that its modern forms are the constitutive outcome of nineteenth-century imperial encounters. ${ }^{7}$ Working within a European framework, Bruno Teschke throws Westphalian histories and typologies into fundamental question by demonstrating the "overwhelmingly dynastic nature of the Westphalian order" that sets this absolutist form of sovereignty apart from subsequent modern (impersonal, bureaucratic, capitalistic) forms. ${ }^{8}$ Such criticisms reveal modern sovereignty to be less the pluralist product of religious conflict and more the dominative products of imperial and class conflict. These debates also demonstrate the historically instable nature of an idea whose essence is the claim to stability. ${ }^{9}$

Analogies to sovereignty certainly existed along the Indian Ocean littoral before British rule. In his study of the littoral, Sugata Bose offers a useful way to provincialize sovereignty:

Precolonial states and polities generally possessed a shared and layered concept of sovereignty, which had helped create certain autonomous spaces for the inhabitants of port cities. Surat and Aden, for instance, had been part of the great land-based Mughal and Ottoman Empires, "yet they had autonomy enough not to be unduly harassed by their inland masters." The notion of indivisible and unitary sovereignty imported under colonial conditions from Europe represented a major break from ideas of good governance and legitimacy that had been widespread in the Ottoman, Safavid and Mughal domains and their regional successor states. Moreover, the British juxtaposed with their own monolithic sovereignty a particularly fake version of sovereignty invested in reinvented 'traditional' rulers in post-1857 India (such as that in Kashmir), and extended it to coastal polities in the Arabian Sea, the Persian Gulf, and the Bay of Bengal around the turn of the century. ${ }^{10}$

This "layered and shared" idea of sovereignty suggests itself for the Swahili city-states of pre-colonial East Africa, bound not by state power but through

\footnotetext{
${ }^{7}$ Radhika Mongia, "Historicizing State Sovereignty: Inequality and the Form of Equivalence," Comparative Studies in Society and History 49 (2007): 384-411; and Antony Anghie, "Finding the Peripheries: Sovereignty and Colonialism in Nineteenth-Century International Law," Harvard International Law Journal 40 (1999): 1-81.

${ }^{8}$ Benno Teschke, The Myth of 1648: Class, Geopolitics, and the Making of Modern International Relations (London: Verso, 2003), 245. For Teschke, sovereignty was literally the family business of rentier royals; its modern transformation only came about with the international domination of the Hanoverian British state controlled by capitalist landed classes.

9 This paradoxical quality of sovereignty emerges in Krasner's historical realist account ("organized hypocrisy"), and more explicitly in Schmitt's metaphysical tract Political Theology, which asserts that the sovereign is "he who decides on the exception," for "the legal order rests on a decision and not on a norm." Carl Schmitt, Political Theology: Four Chapters on the Concept of Sovereignty (Chicago: University of Chicago Press, 2005), 5, 10. Agamben elaborates: "The sovereign is, at the same time, outside and inside the juridical order." Giorgio Agamben, Homo Sacer: Sovereign Power and Bare Life (Stanford: Stanford University Press, 1998), 15. Agamben's paradox is illuminated in William Rasch, Sovereignty and Its Discontents (London: Birkbeck Law Press, 2004), ch. 5.

${ }^{10}$ Sugata Bose, A Hundred Horizons: The Indian Ocean in the Age of Global Empire (Cambridge, Mass.: Harvard University Press, 2006), 25. He quotes from Ashin Das Gupta and M. N. Pearson, India and the Indian Ocean, 1500-1800 (Calcutta: Oxford University Press, 1987), 13.
} 
family ties, ideologies, and trade. The Muslim patrician lineages that controlled these towns through royal courts or councils greatly elaborated their extracontinental genealogies and superior civilization to non-Muslim neighbors, but relied heavily on hinterland clients for trade and protection. ${ }^{11}$ Portuguese first arrived in East Africa in 1498 and exercised an uneven colonial presence along the Swahili coast until the eighteenth century. They maintained the title of sultan ("king" to the Portuguese) for leaders appointed to city-states in Portuguese control, while arrogating control over city trade. ${ }^{12}$ The BuSaidi Sultanate, which physically relocated from Oman to Zanzibar in 1832, similarly retained for itself control over city trade, and represents the first attempt to impose the sovereignty of a single sultan along the entire coast. But Zanzibar was less an "empire" than a commercial enterprise loosely bound by political agents and mercenary debt collectors, heavily reliant upon the consent of local Arab and Swahili elites in the major coastal towns. ${ }^{13}$ Coastal sovereignty both before and during BuSaidi rule implied suzerainty, or control over a vassal state's foreign affairs, while allowing the vassal state to control its own internal affairs. The Ottoman Empire epitomized such a suzerain or vassalic systemindeed, northern parts of the Swahili coast had fallen under nominal Ottoman suzerainty in the latter's struggle against the Portuguese in the sixteenth and seventeenth centuries. ${ }^{14}$ Spheres of local autonomy persisted along the coast throughout these imperial developments, and the Sultan of Zanzibar himself formally acknowledged claims by the Twelve Tribes of Mombasa for "Swahili home rule.",15

But Bose's model also implies that newly imposed juridical claims of European empires equated with the historical experience of colonial subjects, and that this development subsequently divides pre-colonial and colonial subjectivities along the Indian Ocean. Bose, like authors who stress the constitutive nature of sovereignty produced in the interactions between metropole and colony, ${ }^{16}$ necessarily privileges the colonial moment. By framing colonial-era sovereignty as another "derivative discourse," such approaches risk overlooking

\footnotetext{
11 For useful overviews, see Randall Pouwels, Horn and Crescent: Cultural Change and Traditional Islam on the East African Coast, 800-1900 (Cambridge: Cambridge University Press, 1987); Mark Horton and John Middleton, The Swahili: The Social Landscape of a Mercantile Society (Oxford: Blackwell, 2000); and Derek Nurse and Thomas Spear, The Swahili: Reconstructing the History and Language of an African Society, 800-1500 (Philadelphia: University of Pennsylvania Press, 1985).

12 See, inter alia, G.S.P. Freeman-Grenville, The Mombasa Rising against the Portuguese 1631 (London: Oxford University Press, 1980), xxii-xxv.

${ }^{13}$ For an overview, see Jonathon Glassman, Feasts and Riot: Revelry, Rebellion, and Popular Consciousness on the Swahili Coast, 1856-1888 (Portsmouth: Heinemann, 1995); for Mombasa, see F. J. Berg, "Mombasa under the Busaidi Sultanate: The City and Its Hinterland in the $19^{\text {th }}$ Century" (Ph.D. diss., University of Wisconsin, 1975).

${ }_{14}$ See Horton and Middleton, The Swahili, ch. 4.

15 F. J. Berg, "The Swahili Community of Mombasa," Journal of African History 9 (1968), 54.

16 Cf. Mongia, op. cit.
} 
the quieter but resilient continuities of local political legitimacies. In this sense, what is remarkable about mwambao is its expression of what might be termed a "coastal Islamic sovereignty" that predated and postdates the political episode itself.

"Islamic sovereignty" is no less resistant to definition than its modern European analogue. Normative-minded accounts locate Islamic sovereignty in Allah, whose names exhibit his sovereign powers (Arabic, al-Hakimiyya). ${ }^{17}$ Neither kingship nor popular sovereignty has any proper Islamic basis; people retain only the right of subordinate legislation to laws of the Qur'an and Sunnah. ${ }^{18}$ The term sultan, Bernard Lewis argues, had become "the usual Islamic title of sovereignty" by the eleventh century, and was the "standard title used by a monarch claiming to be the head of a state and not recognizing any suzerain or superior."19 The Swahili coast had long had its self-titled sultans-Ibn Battuta met such figures in Mogadishu and Kilwa in 1331and the Sultan of Zanzibar to some extent inherited the glow of religious authority attached to these local Islamic offices. The 1895 treaty and subsequent years of colonial rule preserved explicitly Islamic elements of sovereignty through a political panoply of kadhi courts officially endorsing Islamic family law, state-endorsed and unitary maulid and idd festivals timed by a singular authority, and a cadre of administrators theoretically accountable to the Sultan. The figure of the Sultan lent a symbolically important and regionally unique religious continuity to the coast's colonial history upon which mwambao advocates would fasten.

Mwambao's emergence in the 1950s coincided with a major shift in the nature of sovereignty within the international system. The geo-legal transformation that narrowed the possibilities of Africa's decolonization centered on the shift from what Robert Jackson terms "positive" sovereignty before the Second World War to "negative" sovereignty in the post-war system. The "positive" or empirical sovereignty that dominated the pre-war era referred to a set of positive conditions that a state would need to have- - sufficient force to defend itself from outside intervention, sufficient control over its population and resources to evidently self-govern - in order to join the exclusive club of sovereign states. Post-war "negative" or juridical sovereignty, guided by the Atlantic and United Nations Charters that conferred sovereign rights on all nations to selfdetermination, ended the exclusive sovereign club by globalizing sovereignty as an international entitlement; all nations were now to enjoy freedom from

\footnotetext{
17 Islamic notions of sovereignty begin with recognition of the sovereignty of God (Al-Malik) over man, expressed in the tellingly redundant name Al-Malik-ul-Mulk, while man's deputized sovereignty on earth is Al-Hakimiyya or "governorship." M. A. Muqtedar Khan, "Sovereignty in Islam as Human Agency," Ijtihad 1, 10 (1999), at www.ijtihad.org.

18 Ilyas Ahmed, Sovereignty in Islam (Karachi: Allies Book Corporation, 1963), 11, 20, 23.

19 Bernard Lewis, The Political Language of Islam (Oxford: Oxford University Press, 1988), 43-53.
} 
intervention regardless of their positive conditions. ${ }^{20}$ Sovereignty was now granted rather than won, particularly in Africa's decolonization. Jackson writes: "The revolt against the West ceased to be a credible rebellion against colonial power and became instead a worldwide moral campaign against the ideology and institutions of colonialism. The doctrine of negative sovereignty in post-war decolonization is therefore seen most clearly in the international emergence of Black Africa and Oceania. Before this sea change of international legitimacy the complete independence of these areas was rarely contemplated." 21 States, Jackson argues, could no longer be deprived of sovereignty as a result of "war, conquest, partition, or colonialism such as frequently happened in the past. ... The juridical cart is now before the empirical horse." 22

Mwambao thus occurred at a juncture when universal principles of selfdetermination trumped historical prerogatives of collaborative sovereigns; when colonial-era boundaries sanctified a new cohort of final authorities regardless of each juridical state's effectiveness. But neither mwambao activists nor British officials should be seen, by their failure or design, to be simply facilitating this geo-legal shift, largely because "atomic" nation-state sovereignty was one option, not yet victorious, in a late colonial world where the layered sovereignty of federalism - in British East Africa, the Central African Federation, European Economic Community, British Commonwealth, and French Union-seemed equally plausible. East African federalism offered a potential structure to meet several mwambao claims, and harmonized with larger British thinking about layered Commonwealth sovereignty, embodied in the secondclass but not inconsequential citizenship granted to Commonwealth subjects in the 1948 Nationalities Act. The failures of federalism and circumstances that produced "atomic" nation-state sovereignty across Africa's jagged sovereign landscape varied, but they often involved Britain or France retreating from obligations of labor compensation that were a consequence of their empire's universal claims, to hand over sovereignty to African nationalists who subsequently buried labor claims beneath state projects of nationbuilding. ${ }^{23}$ Also abandoned by retreating European empires were collaborative sovereigns, whose legal status had earlier facilitated the empires' emergence

\footnotetext{
20 Robert Jackson, Quasi-States: Sovereignty, International Relations, and the Third World (Cambridge: Cambridge University Press, 1993), esp. 23-31, 86-91. Jackson's "positive" and "negative" sovereignty roughly equate to Krasner's "domestic" and "international legal" sovereignty, respectively. Critics of Jackson decry the hypocrisy, manipulation, and inequality that infuse the post-war sovereignty system, but do little to refute his core arguments. See Siba N'Zatioula Grovogui, Sovereigns, Quasi-Sovereigns, and Africans: Race and Self-Determination in International Law (Minneapolis: University of Minnesota Press, 1996).

21 Jackson, Quasi-States, 85.

22 Ibid., 24.

23 Frederick Cooper, Decolonization and African Society: The Labor Question in French and British Africa (Cambridge: Cambridge University Press, 1996), 468.
} 
but now posed thorny questions of legal heterogeneity that fueled local debates over sovereignty.

The coast's nominal sovereign figure, Sultan Khalifa bin Harub (r. 19111960), was by the 1950s a mild-mannered closet drinker and tennis enthusiast well into his seventies. ${ }^{24} \mathrm{He}$ enjoyed great prestige, but wielded little of the "originary" transcendent power of the sovereigns theorized by Schmitt and Agamben. The Sultan's power lay in his symbolic appeal among supporters of mwambao. His office, body, anthem, and flag symbolized and sanctified a separate coastal social order. It was through such symbols, above all the Sultan's flag, that an Arab and Swahili elite theorized the contours and content of coastal sovereignty.

\section{THE 1895 AGREEMENT AND COASTAL SOVEREIGNTY BEFORE}

$M W A M B A O$

The mwambao movement (1953-1963) based its claims for autonomy firstly on the coastal strip's "exceptional” legal status expressed in the 1895 treaty. This two-party agreement between Britain and the Sultan of Zanzibar was one of several treaties designed to secure international recognition for state claims to political control during Africa's partition. It enabled the British Government to take over administration and protection of the ten-mile strip from the Imperial British East Africa Company (IBEAC), to whom the Sultan had leased this territory in $1888 .^{25}$ In return, Britain agreed to pay the Sultan $£ 17,000$ per annum indefinitely_ $£ 11,000$ in rent (the amount paid by IBEAC), and $£ 6,000$ in interest ( 3 percent per annum) on $£ 200,000$ the Sultan "lent" to Britain in the treaty. ${ }^{26}$ Realizing the loss of local autonomy, some coastal leaders in 1895 took up political resistance against IBEAC and British encroachment after the latter clumsily intervened in a local office succession dispute. ${ }^{27}$ Sheikh Mbaruk bin Rashid, the aggrieved party, launched the two-year "Mazrui" (or "Mbaruk") Rebellion against the British in Mombasa and along the southern

\footnotetext{
${ }^{24}$ Khalifa bin Harub died on 9 October 1960 at age eighty-one, succeeded by his less popular son Abdallah bin Khalifa. He in turn died on 1 July 1963, succeeded by his still less popular son Jamshid bin Abdallah, who was overthrown on 12 January 1964 and fled to exile in Britain.

25 An 1886 Anglo-German agreement delineated the Sultan's sovereignty from the coastline to ten miles into the interior.

26 The text of the 1895 treaty is in The Kenya Coastal Strip: Report of the Commissioner, Cmnd. 1585 (London: HMSO, 1961). Unlike Germany, which purchased outright the Sultan's rights to the coast of modern Tanzania, Britain leased Kenya's coast from the Sultan. $£ 200,000$ was Germany’s purchase price and therefore estimated to be the Sultan's interest in IBEAC. Britain theoretically "borrowed" this sum - quite literally the same $£ 200,000$ paid to the Sultan by Germany - in a loan repayable at 3 percent interest, without reference to principle repayment. Rent was reduced to $£ 10,000$ per annum in 1924 after the Sultan ceded Jubaland to Italian Somalia. Salim, Swahili-Speaking Peoples, 73; Annexe II of EAC(57)3 entitled "Zanzibar and the Kenya Protectorate," Sept. 1957, CO 822/1810/3.

27 T.H.R. Cashmore, "Sheikh Mbaruk bin Rashid bin Salim el Mazrui," in Norman Bennett, ed., Leadership in Eastern Africa (Boston: Boston University Press, 1968), 109-37.
} 
coast. While some Arab and Swahili joined, others held back, and British forces defeated the disunited coastal community. These unsettled circumstances led conciliatory Britons to draft statements that emphasized the privileged position of sharia on the coast, and to promise implicitly not to abolish slavery, at least not immediately. ${ }^{28}$ People living within the ten-mile strip were technically British-protected persons and subjects of the Sultan, not subjects of the British crown as the rest of Kenya's population became. From the time the mainland formally became a colony in 1920 until independence, the administrative unit of what is today Kenya would bear the awkward title "Kenya Colony and Protectorate."

The treaty exemplified the expedient nature of Africa's partition. Britain took over the IBEAC on the cheap, and the Sultan remained an important figure to legitimize regional agreements, even after coming under formal British protection himself in $1890 .{ }^{29}$ The treaty also represented Britain's ubiquitous reliance upon collaborative authorities. It had relied in similar formal fashion upon the Kabaka of Buganda in the 1900 Uganda Protectorate, and innumerable other agents in East Africa not recognized by international treaty-either internally formalized through "Native Authorities" of indirect rule in Tanganyika, or territorialized through "Native Reserve" chiefs in Kenya Colony. Pre-colonial Zanzibari titles such as liwali (governor), mudir (lieutenant), and kadhi (court judge), which had been fluid appointments along the coast, became formalized administrative offices within the new Protectorate, remaining nominally part of the Sultan's civil service. The Kenya colonial government, which relocated its capital from Mombasa to Nairobi in 1905, exercised ultimate power at the coast through its control over customs and the administrative apparatus to which the Sultan's officers answered. Among British policy changes for the coast, none was more dramatic than the 1907 abolition of slavery. Abolition in part acknowledged the institution's already visible decline, and transformed local systems of surplus extraction from one based firstly on human ownership to one based firstly on land ownership in a largely unsuccessful attempt to realize a capitalist rural economy in coastal Kenya. ${ }^{30}$

In the years leading up to the Second World War, the 1895 treaty stood mainly as an awkward administrative measure, its annual payments a nuisance for Nairobi and an economic safeguard for Zanzibar. Britain had considered outright annexation of the strip in 1917 to override nagging legal questions of naturalization for military service. When the Zanzibar Resident proposed

28 Salim, Swahili-Speaking Peoples, 73.

29 Britain brought its Malaya protectorate model to Zanzibar, where the British Resident ran the government in the name of the prince. Thomas Metcalf, Imperial Connections: India in the Indian Ocean Arena, 1860-1920 (Berkeley: University of California Press, 2007), 42.

${ }^{30}$ Frederick Cooper, From Slaves to Squatters: Plantation Labor and Agriculture in Zanzibar and Coastal Kenya, 1890-1925 (New Haven: Yale University Press, 1981). 
to the Sultan that he simply hand over the coast to Britain in 1919, he "received the proposal complacently saying that he was the child of H.M.G. and was always ready loyally to carry out its wishes." Britain, however, dropped the matter, fearing diplomatic difficulties with France in securing the treaty's abrogation. $^{31}$ In 1930, the Sultan of Zanzibar-then in personal financial difficulty - offered to sell the coast to the Kenya for $£ 250,000$, but the latter unwisely refused, never again to have a similarly simple opportunity. ${ }^{32}$ Some fictive rights of "layered" coastal autonomy withered away during this period. The Kenya Government stripped the "Twelve Tribes" of their annual customs annuity paid in lieu of their long-standing right to collect customs under the Sultan during the First World War. ${ }^{33}$ Indeed, three of the treaties with the Sultan, dating from the 1830s, held a totemic quality among the two sections ("Three Tribe" and "Nine Tribe") of the Twelve Tribe Swahili community of Mombasa, since their tamim (leaders) used the treaties to assert their communities' latent sovereignty. They championed this argument during the inter-war period when the "Arab" community sought to restrict communal voting membership to immigrant Arabs and exclude "Twelve Tribe" Swahili. ${ }^{34}$

Such colonial-era identity politics represent a break with the past, when identities were negotiated through more fluid relations of clientage and intermarriage. Arab, Swahili, and Mijikenda ${ }^{35}$ affiliations hardened through colonial categorization by race and tribe that formalized prevailing status hierarchies, a process reinforced by political organizations confronting colonial power. ${ }^{36}$ After the Second World War, the coast's Arab population launched a lobbying effort to help Arabs "catch up" with other groups in Kenya. Mixed together with demands on colonial improvement schemes were bolder claims about the nature of the Sultan's sovereignty over the coast, led by Arab politicians

31 Note of Bronney[?] to Buist, 24 Oct. 1960, CO 822/2163/42.

32 "Note on Sovereignty of the Sultan of Zanzibar in the Protectorate of Kenya," 21 Jan. 1953, by EJAL/JEA [Kenya Attorney General], KNA GH/32/62/28; Annexe II of EAC(57)3, Sept. 1957, CO 822/1810/3.

33 "A Short Description of the Twelve Tribes" by Hyder Mohammed, n.d. [c. Dec. 1944], KNA DC/MSA/2/1/172/77. In fact, these customs allowances had ended by 1900 , though certain recipients retained grants until their death, and a few mistakenly paid after death, until the liwali advised ending all payments in 1921. Minute, 16 Aug. 1934, CO 533/442/13.

34 Photographs of treaties in KNA DC/MSA/2/1/172/78. On this conflict, see Salim, Swahili-Speaking Peoples, ch. 5.

35 Mijikenda, literally "nine towns," refers to the nine ethnic groups (Chonyi, Digo, Duruma, Giriama, Jibana, Kambe, Kauma, Rabai, Riba) that live near the Kenyan coast, maintain ceremonial shrines or kayas, and share a common descent myth. Mijikenda far outnumber Swahili and Arabs, who had pejoratively termed Mijikenda as "Nyika."

36 Justin Willis, Mombasa, the Swahili, and the Making of the Mijikenda (Oxford: Clarendon Press, 1993), 74-76, 109-12; Margaret Strobel, Muslim Women in Mombasa 1890-1975 (New Haven: Yale University Press, 1979), 41. Whereas Willis maintains that 'Mijikenda' identities were largely products of colonial-era patronage networks confronting state power, Spear argues they have a deeper pre-colonial history. Thomas Spear, The Kaya Complex: A History of the Mijikenda Peoples of the Kenya Coast to 1900 (Nairobi: Kenya Literature Bureau, 1978). 
in Zanzibar. When coastal Arabs lobbied for a second elective seat in Kenya's Legislative Council, ${ }^{37}$ the Coast Provincial Commissioner pinned blame on Hadhrami immigrants. He explained: "I do feel it is very important that we should never forget that the Kenya Protectorate is a part of H.H. the Sultan of Zanzibar's domain. These Hadramis are not his subjects; they are an immigrant race who are now seeking to establish themselves as the dominant Arabs of the Protectorate. This is in the opinion of the local Arabs an insult to His Highness and I feel that we must be very careful that we do not cause offence to His Highness." 38

This suggestion of the Sultan's sovereignty disturbed Philip Mitchell, Kenya's Governor, who responded that "the P. C. clearly needs some guidance: the Sultan of Zanzibar has no 'domains' on the Kenya Coast." Rather, the Sultan has merely "leased a strip of his territory sine die to us; it is true that as a matter of courtesy we, probably mistakenly, agreed to fly his flag over Fort Jesus." ${ }^{39}$ Rich and potent projections of coastal sovereignty flourished upon such mistaken courtesies.

\section{SUBJECTIVE SOVEREIGNTY AND SYMBOLS OF THE SULTAN}

Symbols of the Sultan proliferated along the coast after the Second World War. None was more important than the Sultan's flag, as Governor Mitchell had intuited. This plain red flag flew over Fort Jesus and other administrative offices in Mombasa and other coastal towns. The Coast Provincial Commissioner ultimately sanctioned this practice, which dated from 1895, to symbolize continuity with the past, and it became progressively standardized over the 1930s and 1940s. The Provincial Office subsidized this bedecking of coastal centers even during the war's financial deprivations. Shortly after the war, the Provincial Commissioner instructed officers to take better care of this vital symbol: "Our flying of the Sultan's flag in the Protectorate is a courtesy much prized by the many Arabs on the Coast, and, incidentally, any lapses we make in this connection are immediately noticed and commented on. The condition of the flag, whether it is promptly raised and lowered at sunrise and sunset, etc., are matters of importance to them." Special large flags of the Sultan were flown on Fridays, Islamic holidays, Empire Day, the King's Birthday, and Christmas Day, "and other suitable important occasions."

\footnotetext{
37 President, Central Arab Association to Kenya Governor, 5 Mar. 1950, KNA OP/1/546/43/1. Representation in Kenya's Legislative Council was defined racially, with Arabs holding one elected seat and one appointed. The colonial administration felt Arab elected representatives functioned badly in office because of their poor English, and preferred to retain the appointed position.

38 Provincial Commissioner [hereafter PC] Coast to Chief Secretary, 10 Mar. 1951, KNA OP/1/ $546 / 151$.

39 Minute of Mitchell, 24 Mar. 1951, KNA OP/1/546/155.

40 Acting PC Coast to all District Commissioners, 21 Feb. 1946, KNA DC/Lamu/2/11/19/49. Small flags were flown over all district headquarters on the coast. Acting PC Coast to District Commissioner [hereafter DC] Kilifi and Lamu, 10 Mar. 1947, KNA DC/Lamu/2/11/19/59.
} 
Mudirs throughout the Protectorate seized this opportunity and regularly reordered Sultan's flags paid for by British administration funds. ${ }^{41}$

A subtle but important distinction separated the flying of the Sultan's flag from that of the Union flag. In the Protectorate, only the Sultan's flag could be flown from poles affixed to the ground; the Union flag could only fly from British buildings. In declining a request from a Briton to fly the Union Jack from the ground of his own home, the Coast Provincial Officer stated that he knew "of no one in this Province who flies the Union Flag from the ground." 42 In Nairobi, administrators were regretting this extension of sovereign courtesy. Lawyers determined, "The practice whereby the Zanzibar flag is flown from Fort Jesus and Lamu Fort is an act of courtesy which does not appear to have any basis in protocol." 43 When the King's African Rifles doubted the Sultan's sovereign status and refused him a twenty-one-gun salute, the British Resident in Zanzibar protested, noting that the Sultan had always been accorded this, and that if any doubt remains, "it can be overcome by saluting his flag." "44 Subsequent legal research into this topic in Nairobi was haphazard and characterized by wishful thinking. The Solicitor General concluded that the wider distinction between Protectorate and Colony meant little because the Sultan had already surrendered critical elements of sovereignty in the 1895 agreement. $^{45}$ As the legal issue grew more urgent, however, Whitehall lawyers determined that the Sultan retained substantial sovereignty over the coast. Sidney Abrahams found that the agreement's recognition of the Sultan's sovereignty was not simply "invented to soothe ruffled Sultanic pride," but was legally substantial because "Protectorate" expressed both the protector's interest in the protected territory and, crucially, "the opportunity of abandoning the Protectorate without the complications that would arise from the cession or relinquishment of territory being a part of the dominions of the Crown."46 Colonial Office legal opinion concluded that should Britain give up administering the Protectorate and transfer its responsibilities either "to a self-governing Kenya Government or to an East African Federal Government, a new Agreement would be required."47

If Nairobi officials were dull to the status of sovereignty, coastal observers took careful note of its symbols and meanings. The Kenya Protectorate Nationalist Party, one of several mwambao parties, explained: "The flying of a red flag at all Government stations in the Kenya Protectorate is not without historical

${ }^{41}$ See correspondence in KNA DC/Lamu/2/11/19.

42 PC Coast to DC Lamu, 14 Nov. 1952, KNA DC/Lamu/2/11/19/158.

43 "Note on Sovereignty," loc. cit.

${ }^{44}$ British Resident, Zanzibar to Governor Kenya, 21 Jan. 1953, KNA GH/32/62/22.

${ }^{45} \mathrm{Ag}$. Solicitor General to Chief Native Commissioner, 26 June 1951, KNA OP/1/546/167.

46 Opinion of Sydney Abrahams, January 1951, Annexe III of EAC(57)3, entitled "Zanzibar and the Kenya Protectorate," Sept. 1957, CO 822/1810/3.

47 "East African Conference," Colonial Office, Dec. 1960, CO 822/2163/49. 
background in a bona fide recognition of the distinctive separate state of Mwambao from the Kenya Colony. The red flag or any other flag hoisted with its pole pitched to the ground signifies in international law "Sovereignty.",48

Local histories ascribed great significance to distinctions in flag-flying practice. A Lamu historian wrote, "The Sultan's flag flew every day from a mast planted in the ground. The English flag [instead] flew above English officer buildings to show it was not their colony." "I9 In 1949, Arab politicians and administrators, working alongside British officials, launched a veritable campaign of symbols to revive the Sultan's position on the coast in celebration of his seventieth birthday. ${ }^{50}$ The assistant liwali in Mombasa reported, "Every house and shop occupied by His Highness' subject the Sultan's flag was seen waving" on his seventieth birthday. ${ }^{51}$ By this time the political language of flags on the coast had largely transformed from earlier understandings of the 1880s, when the Sultan's banner represented not national sovereignty but rather "the prestige of the Busaid dynasty and the personal patronage of the sultan." 52 Indeed, it was the German lowering of the Sultan's flag that sparked the 1888 Abushiri rebellion along the mrima coast of modern Tanzania. It revealed to rebels not a new order of European imperialism but rather the Sultan's failure to live up to his obligations as patron. ${ }^{53}$ By the 1950s, however, the symbol of the flag no longer simply communicated the figure of the Sultan as patron, but also the Sultan as territorialized national authority figure fully recognized by Britain. This was acknowledged even by mwambao opponents, who contested the legality of the 1895 treaty but implicitly accepted the political language of flag sovereignty. A coastal branch of the Kenya African National Union (KANU) opposing mwambao declared, "The Arab imperialism must go and the red flag must disappear."

Other symbols marking the Sultan's sovereignty crested during the mwambao years. Programmers at Sauti ya Mvita ("Voice of Mombasa"), the provincial radio station funded largely to counter hostile broadcasts from Radio Cairo, ensured that the flag's acoustic equivalent, the Sultan's national anthem, began each morning and evening broadcast. ${ }^{55}$ Recordings of the

48 KPNP to Robertson, 25 Sept. 1961, CO 894/12/20.

49 Ahmed Mohammad Ahmed Al-Jahadhmy, Tarekhe ya Amu (written 1968, self-published 1985), 24; my emphasis, author's translation. I thank Jamal Mahfoud Al-Jahadhmy and Andy Eisenberg for providing access to this work.

50 A year later, a reporter wrote, "It took some effort to be cognizant of the ties attaching this coast to the Sultanate," but noted that the seventieth-birthday celebration "drove home to those who had been ignorant the fact that Mombasa still holds on its shores a community cherishing an affectionate regard for the Sultan of Zanzibar." Mombasa Times, 29 Sept. 1950.

51 Azzan to DC Mombasa, 6 Sept. 1949, KNA CA/16/63/11.

52 Glassman, Feasts and Riot, 202.

53 Ibid., ch. 7.

54 KANU Kwale Branch to Robertson, n.d. [c. Oct. 1961], CO 894/13/15.

55 Coast Broadcasting Advisory Sub-Committee minutes, 14 June 1957, KNA AHC/30/8/3. 
Sultan's speeches sent from Zanzibar were played regularly, as were his greetings to open and close Islamic festivals such as idd and maulid. This medium enjoyed enormous expansion during the mwambao years, as radios became regular features in public squares, coffee shops, restaurants, and Mombasa homes. They were particularly common in homes of mwambao supporters; 53 percent of "Arab-Swahili" households in town had a radio, against the town average of 15 percent. ${ }^{56}$ Growth in sovereign dress complemented this sonic expansion. The liwali or Sultan's deputy for the coast, Sheikh Mbarak Ali Hinawy, conveyed the Sultan's symbolic martial power by opening the Idd al-Hajj baraza dressed in "traditional Arab costume ablaze with colour, ceremonial sword at his side and a jeweled dagger in a silken sash." 57 Some Protectorate civil servants wore a red fez with star to symbolize the unitary figure of the Sultan. Mwambao advocates expanded this dress to non-government workers by designing and distributing hats and ties dyed in red with three stars rather than one. Passing through Kenya in 1958, Ali Muhsin al-Barwani noted, "A group of friends and well-wishers waited to meet me at Mombasa airport, some of them ostentatiously displaying their red three star tie, denoting the two islands and the coastal strip of Kenya, which was part and parcel of the Sultanate of Zanzibar." "58 Some ten thousand people arrived to welcome him that day, not just with ties but red flags, badges, and party banners, eliding symbols of the Sultan, the coastal Protectorate civil administration, and Ali Muhsin's Zanzibar Nationalist Party (ZNP). ${ }^{59}$

The significance of the Sultan's sovereignty lay not in the exercise of autonomous administrative power, but in the emotion-laden aspirations of his self-chosen "subjects" or raiya - the Swahili term used also to denote "citizens." The figure of the Sultan himself imparted immense local prestige. After successfully inviting him to visit the Arab Women's Institute at Mombasa in 1957, Shamsa Mohamed Muhashamy recalled, "This was the first really beneficial thing we did, and all women now knew that we had become equals. ${ }^{60}$ By the late 1950s, the Sultan's birthday ranked alongside maulid and idd as the coast's principal festivals. Cries of "long live the Sultan" filled coastal towns during this celebration. In Mombasa, massive torch-lit processions through crowd-thronged streets included stick dancers, banners of the Sultan, and lorries carrying brass bands. Famous poets offered verses of praise over loudspeakers. ${ }^{61}$ In trying to determine the

56 Question and Answers, Mombasa Social Survey, G. M. Wilson, 7 Nov. 1958, KNA DC/MSA/ 2/1/3/p. 12 .

57 Mombasa Times, 11 Aug. 1954.

58 Ali Muhsin al-Barwani, Conflict and Harmony in Zanzibar (Memoirs) (Dubai: self-published, 2000), 106.

59 Zanzibar Intelligence Report, June 1958, CO 822/1377/52.

60 Strobel, Muslim Women in Mombasa, 189.

61 See Mombasa Times, 8 Sept. 1954, and 27 Aug. 1957. 
substance of the Sultan's sovereignty, the Robertson Commission observed, "The only manifestation of it on the coast of Kenya is his flag, which flies everywhere in the Strip and even in the Witu lands which are outside it." It concluded, "His sovereignty is, therefore, very nebulous and little more than a vague sentimental idea. Even so, many of the Arab inhabitants look as much to the Sultan as to the British Government for protection of their interests and, although the Sultan's sovereignty means little in its practical effect, I was convinced by my many interviews with Arab and other Muslim inhabitants of the Coast that emotionally it is a factor which cannot lightly be put aside." 62

Sovereignty existed above all in the minds of the Sultan's willing subjects. It represented a bundle of claims with historical roots that coastal autonomists asserted in the face of an ascendant African nationalism that explicitly sought to overturn coastal political structures. These claims faced overwhelming obstacles in the partisan landscape of Kenya's decolonization.

\section{FRACTURED PARTY POLITICS AND THE ROBERTSON COMMISSION}

While the mwambao movement united around reinvigorated symbols of the Sultan's sovereignty, it fractured under stress of coastal party factionalism, united Kenya African opposition, and Britain's desire for expedient decolonization. Unlike Zanzibar, where the two principal parties-ZNP and Afro-Shirazi Party (ASP) - fairly represented two powerful and contrasting ideological viewpoints, both mwambao and anti-mwambao parties were too numerous and divided to allow for a straightforward political history. ${ }^{63}$ These parties represented not only the multiple social divisions along the coastal strip, but also the multiple territorial units upon which political ambitions were projected: the ten-mile strip (mwambao); the much larger Coast Province, whose own autonomy, captured in the term majimbo-ism, was championed by mainly Mijikenda supporters of the Kenya African Democratic Union (KADU); and a centralized, Nairobi-dominated Kenya supported primarily by KANU upcountry immigrants. The Kenya Government proscribed African political parties in 1953 during Mau Mau, and when the ban was lifted in 1955 only district-level parties were permitted. ${ }^{64}$ The four major parties involved in fighting either for or against mwambao all formed branches in Mombasa and other coastal towns only in late 1960. The two main political parties to support mwambao were the Coast Peoples Party (CPP), the most articulate and aggressive coastal party led by Swahili and Arabs in

62 Kenya Coastal Strip, 13.

63 The best political history for Zanzibar remains Michael Lofchie, Zanzibar: Background to Revolution (Princeton: Princeton University Press, 1966); for mwambao, Salim, "The Movement for 'Mwambao."”

${ }^{64}$ A. J. Hughes, East Africa: The Search for Unity (Harmondsworth: Penguin, 1963), 123; Keith Kyle, The Politics of the Independence of Kenya (New York: St. Martin's Press, 1999), 70. 
Mombasa; and the more conservative, Arab- and European-dominated Coastal League. $^{65}$ They were joined by the Lamu-based Shungwaya Freedom Party, a Bajuni-dominated party concerned not only with mwambao but also the emerging border crisis with Somalia, and the Malindi-based Kenya Protectorate Nationalist Party (KPNP), an Arab-led party that resented Mombasa's leadership of mwambao. Several other smaller and short-lived parties followed. One CPP activist recalled, "When we opened our eyes there were here at the coast about thirty parties competing with CPP." ${ }^{66}$ CPP leader Abdullahi Nassir offered the most progressive political vision among mwambao parties. He attempted to distance the movement from its widely-perceived Arab elitism by mobilizing a wider "Swahili" population to include those Africans who identify with coastal culture, and thereby better capture the sociological complexities of coastal society beyond its binary caricature of Arab landlord/ ex-master and African squatter/ex-slave. ${ }^{67}$ But such caricatures could also mobilize support, and the popularity of mwambao often turned on fears of African domination. The comic picture of European planters in Malindi championing the Sultan's sovereignty while mumbling distrust of CPP urban radicals revealed the considerable opportunism and ultimate socio-economic incoherence of mwambao party politics. ${ }^{68}$ Party leadership was mostly weak, for highly talented Arab and Swahili civil servants on the coast, who all supported autonomy and were the movement's natural leaders, were prohibited from participating by dint of their positions. ${ }^{69}$ Generally speaking, the more "royalist" Coastal League sought union with Zanzibar, while the CPP sought an autonomous or independent coastal state detached from the Sultanate, in both cases based on the coast's "exceptional" historical sovereignty from the mainland.

The first sustained calls for coastal autonomy were led by Arabs in Zanzibar and Kenya inspired by political events in the Middle East. In 1948, two leaders of Zanzibar's Arab Association and liwali of the Kenya coast, Mbarak Ali Hinawy, visited London to petition the Colonial Office for 'Arab independence' on

65 Kindy, Life and Politics, 188-89.

66 Sarah Mirza and Margaret Strobel, eds., Three Swahili Women: Life Histories from Mombasa, Kenya (Bloomington: Indiana University Press, 1989), 111.

67 Nassir's most articulate expression of political leadership is captured in his cyclostyled petition to the Coast Provincial Commissioner that attacks the elitism of Mombasa's Arab bureaucratic and political leadership, entitled "Pwani ya Kenya," 4 Feb. 1960, in KNA CA/10/126/11. The Kenya Government had in 1952 'promoted' the Twelve Tribes to Arab status.

${ }^{68}$ See minutes of Malindi European Association, 27 Sept. 1961, in Malindi European Association Papers, Rhodes House (Oxford University), Mss.Afr.s.564, vol. II.

69 Liwalis, Mudirs, and Kadhis of Kenya Protectorate to Maudling, n.d. [c. Feb. 1962], CO 822/ $2151 / 84$. Hyder Kindy, for example, did not publicly express his views on mwambao and later dismissed it as a "fiasco" in his memoir Life and Politics in Mombasa, written while employed by Kenyatta's government. But in fact he was a staunch supporter of autonomy; see his petition to Robertson Commission, 19 Oct. 1961, CO 894/13/10. 
Zanzibar. ${ }^{70}$ Mombasa Arabs used the pages of Mwongozi, the main Zanzibari nationalist newspaper, to proclaim their loyalty to the Sultan in fulsome terms. ${ }^{71}$ Arabs from all four British East African territories met at Mombasa in 1953 to form the East African Arab Union, which sought "the realization of unity of the dominions of His Highness the Sultan of Zanzibar." Seeking to confirm the Sultan's "ownership" of the coast, the organization also sought to revise the 1895 treaty to increase the $£ 10,000$ annual rent, since this amount did not match "the present and potential value of this land, economically, politically, and strategically," and thus the Sultanate was not "enjoying the full benefits of its sovereignty over us." ${ }^{\text {72 }}$ Arabs from Zanzibar had established important political links with Egypt after the Second World War, and they used these ties to broadcast anti-colonial polemics on Egypt's radio airwaves. Ahmed Said, Egypt's "Voice of the Arabs" program announcer, celebrated mwambao as an anti-colonial struggle: "O! Arabs. News has reached us that an Arab Islamic Nation is being established in Zanzibar and the Coastal Strip of East Africa ... It is our duty then, to assist this blessed movement, so as to glorify it, support it and bring it up to join our Arab Procession.... Arab Nationalism is penetrating the East African Jungle and Central Africa. The Arab League of Nationals on the one hand and the Arab Nations extending from the Atlantic to the Arabian Gulf, on the other hand should help our Brothers in Kenya and Zanzibar., 73

Swahili-language broadcasts from Cairo remained sympathetic to mwambao until $1960 .^{74}$ A. I. Salim dates mwambao's start to 1956 , when, amidst the growing Suez crisis, Kenya's two Arab Legislative Council members contested a proposal to establish a British naval base at Mombasa, claiming that the Sultan's sovereignty and Arab consent were being trammeled. ${ }^{75}$

This internationalization of mwambao provoked African nationalist hostility that led to a Zanzibari retreat. Robust opposition to coastal autonomy first emerged in Francis Khamisi's Mombasa Democratic African Union (MADU) party. MADU pursued its own newspaper war against Mwongozi by insisting that there was only one mfalme (sovereign) in East Africa-the Queen, not the Sultan. ${ }^{76}$ Khamisi launched a 1958 campaign to oppose

70 S.L.O. Intelligence Survey for period ending 10 Nov. 1948, CO 537/4340/1. Before this trip, Hinawy had requested official papers documenting the relationship between the Sultan and Britain. Glenday to Cohen, 16 July 1948, CO 537/4706A/1.

71 See, inter alia, letter of "Four-Of-A-Kind," Mwongozi, 30 Jan. 1953.

72 Mombasa Times, 29 Dec. 1953; 1953 Mombasa District Annual Report, KNA DC/MSA/1/5.

73 Saut el-Arab broadcast, 30 June 1956, Foreign Office [Kew] 371/119222/E1433/76.

74 On Radio Cairo's Swahili-language broadcasts, see James Brennan, "Radio Cairo and the Decolonization of East Africa, 1953-1964," in Christopher Lee, ed., Bandung and Beyond (forthcoming).

75 Mombasa Times, 28 May 1956; Salim, "Mwambao,” 216-17.

76 Sauti ya $M A D U, 10$ Aug. 1958. 
mwambao by enrolling support of more powerful upcountry politicians. Contra the East African Arab Association, Khamisi argued Kenya should cease paying any rents to Zanzibar. ${ }^{77}$ MADU was quickly overshadowed by national organizations, and by late 1960 opposition to mwambao was shared by the two major political parties: the Kenya African Nation Union (KANU) supported by upcountry Luo and Kikuyu, and the Kenya African Democratic Union (KADU) led by Ronald Ngala and supported by Mijikenda and other "minority tribes." KANU favored a powerful unitary government in Nairobi; KADU feared national domination by the former and preferred a system of regional autonomy, but pointedly refused to extend this principle to support coastal autonomy. Both parties were equally hostile towards mwambao, for it represented the continuation of coastal Arab and Swahili privilege over Africans. ${ }^{78}$ This strikingly unified opposition to mwambao among African nationalist parties otherwise at odds convinced Zanzibari nationalists to abandon the cause. In April 1960, ZNP dramatically broke from its earlier unconditional support of mwambao and its demand that the coast be reunified with Zanzibar, and left it to the coastal people to decide their own future. ${ }^{79}$ This became one of the few points of consensus between ZNP and ASP in their otherwise bitter political competition. A year later, Zanzibar's Sultan Abdallah bin Khalifa meekly agreed to this consensus of non-interference. ${ }^{80}$ Despite this abandonment, mwambao supporters continued to travel to Zanzibar to petition the Sultan for autonomous government in the Kenya Protectorate, appealing to fears of domination by "up-country peoples." 81 In 1963, ZNP Prime Minister Mohamed Shamte politely explained to the Tamim of Mombasa's "Three Tribes" that there was nothing more Zanzibar could do for mwambao. ${ }^{82}$

Only when mwambao became a national issue did the Kenya Governmentnow committed to an orderly decolonization - fully face the implications of the 1895 treaty. Mwambao had gained sustenance in the ambiguity of East Africa's constitutional future. Although no British official ever considered full independence a possibility, the coastal strip could have conceivably gained some measure of autonomy if it had remained within a Federated East Africa

77 Scotsman, 16 June 1960, in CO 822/2163/28.

78 On KANU-KADU competition, see Kyle, Politics, ch. 7; and David Anderson, "Yours in the Struggle for Majimbo': Nationalism and the Party Politics of Decolonisation in Kenya, 1955 to 1964," Journal of Contemporary History 39 (2005): 547-64.

79 Mooring to Macleod, 27 Apr. 1960, CO 822/2163/18.

${ }^{80}$ Note on visit to Sultan of Zanzibar by W. T. Hull, Robertson Commission Secretary, 7 Oct. 1961, CO 894/3/7. Hull found "that Zanzibaris of all kinds are fearful of taking any line which will antagonize up-country African opinion.” Hull to Kitcatt, 25 Oct. 1961, CO 894/1/125.

81 Petition enclosed in Mooring to Webber, 19 May 1960, CO 822/2163/20.

82 Sheikh Ali bin Mohamed bin Yunus, Tamin of "Three Tribes" to Sultan of Zanzibar, 7 Oct. 1961, KNA CA/26/5/1; Muhamed Shamte to Sheikh Ali bin Mohamed bin Yunus, 26 Aug. 1963, in private collection of Abdulkarim Yunus, Mombasa. I thank Jeremy Prestholdt for providing a copy of this document. 
bound by a fully integrated customs and transport policy. ${ }^{83}$ Federation enjoyed an odd constituency of pan-African idealists and calculating British administrators. Created in 1948 to coordinate inter-territorial services, the East African High Commission had been a popular target of hostile African nationalists, but Julius Nyerere pressed for continued inter-territorial cooperation, and thus kept open this constitutional door as each territory approached selfgovernment and independence. ${ }^{84}$ In June 1960, Kenya's Governor finally asked the Colonial Office to consider "to what extent the Protectorate, should it become an autonomous province, could be a viable entity," while instructing Treasury to ascertain the Protectorate's financial position. He offered two possibilities: that the Protectorate retain its autonomy in a federation with guarantees that Mombasa provide services to Kenya and Uganda, or that Mombasa alone fully join Kenya. Treasury determined neither scenario was viable. $^{85}$

To resolve these mounting legal questions, the Colonial Office appointed Sir James Robertson, ex-Governor of Nigeria, to lead a commission to determine whether the 1895 treaty should be amended or abrogated in light of the constitutional futures of Kenya and Zanzibar. In correspondence that led to the commission's formation, the Colonial Secretary Ian MacLeod indicated that a timely decision was required, since both he and the Kenya Governor had agreed to prioritize discussions with the major political parties (KANU and KADU) that would include internal self-government. In a striking and unexplained turnabout, ${ }^{86}$ MacLeod abandoned federation as a solution, calling it "open to serious question," for "the Strip, as it stands, is not a viable administrative unit." Therefore, like so many before it, this commission's conclusions were reached at the start. MacLeod instructed the British Resident in Zanzibar:

The only practical solution is that the Strip as a whole can only be administered as part and parcel of Kenya. ... The best in my view one could then aim for would be virtually a maintenance of the status quo but with Kenya taking over the role of H.M.G. under the 1895 Agreement. Our problem therefore would be to make this change-over with proper regard for the Sultan's sovereignty and the legitimate interests of the Arabs in the Strip,

83 Even Philip Mitchell, Kenya's most pro-Arab governor since Hardinge, had admitted the coastal strip had "no political future" detached from mainland Kenya. Mitchell to Creech Jones, 24 Feb. 1948, CO 537/5911/8.

84 Joseph Nye, Pan Africanism and East African Integration (Cambridge, Mass.: Harvard University Press, 1967), 133. Nyerere had founded the Pan-African Freedom Movement of East and Central Africa (PAFMECA) in 1958, and worked to establish the East African Common Services Organization in June 1961. Ibid.

${ }^{85}$ Renison to Webber, 10 June 1960, CO 822/2163/27. The Robertson Commission later found a $£ 955,000$ shortfall between revenue and expenditure on the coastal strip. Kenya Coastal Strip, 10.

${ }^{86}$ At an East African Governors' meeting held on 16 June 1961, consensus emerged that it would be best to establish the strip as a High Commission territory, so that it could later become a federal territory after Kenya reached internal self-government. Extract note at CO 822/2164/70. The East African High Commission was renamed the East African Common Services Organisation that same year. 
particularly in land rights, and the protection of Islamic personal law... . I see presentational disadvantage therefore in leaving the initiative in this matter to the politicians in Nairobi and return again to the idea of the Commissioner. ${ }^{87}$

The heads of Kenya and Zanzibar were sympathetic to this conclusion, but feared igniting a regional political conflict in its implementation. Mooring, the British Resident at Zanzibar, warned that it "will be difficult to obtain His Highness's agreement to a solution which does not (repeat not) command the support of the majority of his subjects inhabiting the coastal strip." 88 Kenya's Governor concurred. "Such a solution," Renison explained, "would be unacceptable to non-African inhabitants of the Protectorate and there is reason to suppose that many coastal Africans though unwilling to voice their views in the present atmosphere of political intimidation, would, in the last resort, resist rule by predominantly up country African government." 89 For their part, both KANU and KADU made it clear that the coastal strip had to remain an integral part of Kenya, and they feared that an appointed commissioner might reach a different conclusion. ${ }^{90}$ Petitioners from across the political spectrum bombarded the Robertson Commission when it arrived on the coast in October 1961. Tensions sharpened wherever the Commission traveled. KANU, KADU, and the Kenya Federation of Labour jointly called for a boycott of all Arab shops for the days the Commission met in Mombasa. Gangs of supporters threatened Arab traders and hotel owners, demanding they close shop before the Commission met; seventeen arrests followed and the traders agreed to close to prevent further intimidation. $^{91}$ By the autumn of 1961, veiled and open threats of violence had become a ubiquitous part of anti-mwambao rhetoric among African political leaders. $^{92}$

SOVEREIGNTY'S BUNDLE OF CLAIMS: RELIGION, IMMIGRATION,

LAND, AND HISTORY IN MWAMBAO

Composed at this tense moment but summarizing years and decades of political thought, petitions to the Robertson Commission richly illustrate how coastal political activists envisioned sovereignty. ${ }^{93}$ Discernible patterns of claims and counter-claims emerge. James Sheehan argues that sovereignty was not a legal "chunk" but a practical and functional "basket" of claims that "are

${ }^{87}$ MacLeod to Mooring, 4 July 1961, CO 822/2149/9.

${ }^{88}$ Mooring to MacLeod, 7 July 1961, CO 822/2149/11.

${ }^{89}$ Renison to MacLeod, 15 July 1961, CO 822/2149/15.

90 Renison to MacLeod, 8 Sept. 1961, CO 822/2149/52.

91 Provincial Information Office, Mombasa, 10 Oct. 1961, KNA CQ/9/3/7; Saleh Omar Salmeen [President, Arab Traders Association] to DC Mombasa, 11 Oct. 1961, KNA CQ/9/3/9.

92 These public threats are chronicled in Memorandum of Coastal League to Robertson, App. E, 7 Oct. 1961, CO 894/12/6.

${ }^{93}$ Petitions are in CO 894 series. 
always made with reference to someone else." 94 To pursue this analogy further, sovereignty on Kenya's coast was as a cord twining together related claims to land, political office, religious authority, and immigration control grounded in nineteenth-century norms of coastal Arab and Swahili power. ${ }^{95}$ Arab and Swahili administrative power had withered while its symbols proliferated, British officials having gauged the latter an expedient concession to maintain local consent. Within the colonial-era power shift from coast to upcountry, there is an instructive contrast between the popular sovereignty of African majority rule that won out in East Africa, and the dynastic sovereignty of the Sultanate that found itself superseded. Popular sovereignty was the political extension of modernization paradigms of the day, universal programs for change that mistakenly assumed co-variation of multiple social elements over time-ascribed to achieved status, subsistence to market economy, extended to immediate family households, subjects to citizens. The dynastic sovereignty of mwambao, by contrast, mistakenly assumed co-stasis of such social elements over time within a sovereign territory, and sought to resist larger forces then visibly overtaking coastal politics during East Africa's decolonization - regional racial politics, international nation-state imperatives, and powerful migrant labor networks. Mwambao supporters fought to remain subjects of the Sultan to resist being overwhelmed by an emerging Kenyan citizenry.

Religion emerged as a vital element of sovereignty championed by the Sultan's subjects. Ceremonial baraza, or public meetings, held by British consuls in 1895 at Mombasa and Lamu and long recalled by coastal residents proclaimed that Islam "would remain the public and established creed" in the Sultan's dominions, and that sharia would be maintained. ${ }^{96}$ Staffed by the Sultan's nominal employees, kadhi courts adjudicated personal status law, that is, cases of inheritance, marriage, and divorce. ${ }^{97}$ Mwambao activists argued that Islam itself was under threat by mainland Kenya. A Lamu sheikh warned that if Britain left, an African Kenya government will neither "safeguard our customs or our religion which will be interfered with ... Ngala has stated that he would pull down our mosques and will not allow our fasting as required by our religion after their independence."98 CPP took upon itself the role of defender of the Islamic faith. Its Women's Section

94 Sheehan, "The Problem of Sovereignty," 2-3.

95 These norms color the historiography of the Swahili Coast. See Salim, Swahili-Speaking Peoples; and Pouwels, Horn and Crescent. For a critical perspective on the meaning and contestation of these norms along the nineteenth-century coast, see Glassman, Feasts and Riot.

${ }^{96}$ Salim, Swahili-Speaking Peoples, 73.

${ }^{97}$ Hassan Abdulrahman Mwakimako, "Politics, Ethnicity and Jostling for Power: The Evolution of Institutions of Muslim Leadership and Kadhiship in Colonial Kenya, 1895-1963" (Ph.D. diss., University of Cape Town, 2003), ch. 5.

98 Translation of letter of F. Athman and O. B. Basheikh [Lamu] to Governor's Private Secretary, 22 Aug. 1963, CO 822/3073/E17(ii). 
warned: "Political agitators, mostly from upcountry have very often tried to throw mud on Islam by blaming its teachings as the cause of the backwardness of certain Africans. Threats have been made in public and in private that as soon as independence came the purdah system will have to be discontinued. Mosques will be defiled and the sheria courts discontinued. A number of women have been threatened at bus stops and elsewhere and some forcibly to unveil their faces." 99

Fueling this panic were the competing curricula of Islamic and Christian missionary schooling. Coastal Muslims feared, with good reason, that Christian schoolrooms demonized Arabs as slave traders whom Europeans had removed from power for the benefit of Africans, yet they also recognized that such schools were far better at preparing students for higher education and competitive bureaucratic posts. The KPNP petitioned that "the muslim [sic] schools syllabus and/or curriculum be arranged in such a way as to incorporate religious instructions and Arabic language in a manner that would not hamper a student in attaining a ... pass."100 Islamic autonomy thus offered prospective shelter from educational as well as legal trends that visibly benefited aspiring Christian bureaucrats over their Muslim counterparts in wider Kenya.

Behind these religious fears lay the terrors of demographic imagination. By the late 1950s, roughly four thousand new African immigrants were arriving each year in Mombasa alone. ${ }^{101}$ For mwambao advocates, sovereignty meant immigration control. ${ }^{102}$ The Coastal League stipulated on its enrollment form that the State of Azania (its name for independent mwambao) "shall be governed by the principle that preference shall be given to Wenjeji wa [natives of] Mwambao, and that it is the duty of the State to replace expatriate labour with indigenous labour as soon as the latter can be made capable of assuming the required responsibility." 103 In a decidedly less ecumenical instance of leadership, Abdullahi Nassir sought to delimit the rights of citizenship to only those born within the ten-mile strip:

We would like to explode the fallacy that is very prevalent in this part of Africa, that as long as one has a black pigmentation and fuzzy hair, one has citizenship rights in Africa. Might was right in 1885 and in 1961 Black is right. These people swarming from upcountry in busloads and bogey loads come to earn a living or to shelter from the famine that ravages their country from time to time. They never regard this as their home and they have got their roots firmly entrenched in their own homes.... To grant political rights to such a people, who have no patriotic sentiments to the Coastal

\footnotetext{
99 Memorandum of Womens' Section of CPP, by Mwanawangu Mzee and Somoe Bausi to Robertson, 20 Oct. 1961, CO 894/13/8.

100 Petition of Mohamed Husein Jongoo [President, KPNP] to Zanzibar Sultan, encl. in Husein to Zanzibar Sultan, 29 Aug. 1963, CO 822/3073/E17(iii).

$101 \mathrm{EAC}(57) 3, \mathrm{CO} 822 / 1810 / 3$.

102 A rough 1961 coastal strip census found (by race): 300,000 Africans; 48,000 Asians; 37,000 Arabs, Swahilis, and Bajunis; and 7,000 Europeans. Kenya Coastal Strip, 7.

103 Enrollment form for Coastal League, CO 894/2.
} 
Strip or who have dual loyalties is a mockery of democracy and a direct threat to the well being of the true nationals of this country. This threat looms very large on our heads, the true sons of Mwambao. ${ }^{104}$

The first issue the CPP raised in its meeting with the Robertson Commission was the overabundance of up-country Africans and paucity of coastal people in the Coast Police Force. This posed the danger "that they might just stand by in the event of trouble, such as had happened in Zanzibar." The party requested that the pass system be reactivated. "At present," they argued, "there are about 5,000 unemployed up-country people in Mombasa, and they thought that every up-country person should be returned to their homes, and a barrier set up so that they could not re-enter." ${ }^{\text {105 }}$

As elsewhere in Kenya, the most contentious and intractable conflicts on the coast occurred over land. The connection between land and sovereignty was clear in the political imaginations of both sides of the mwambao debate. Despite recent entries of some European and Indian investors, land ownership patterns of the late 1950s were much like those of the 1910s following the abolition of slavery. The coast remained an undercapitalized agricultural belt dealing in crops (coconut, maize, millet, cassava) marginal to Kenya's export economy. ${ }^{106}$ Lacking any decisive economic transformation, legal pluralism prevailed, with consequent contestations of jurisdictional boundaries. As Hamadin Abd Hamid notes, land matters on the coast were "administered under several forms of law notably Shari'a law, mila [Swahili customary law], and customary law... [t]he problem was that the geographical boundaries of these legal spheres were not defined, in fact the spheres of influence of these laws always overlapped." ${ }^{\prime 107}$ Although the ten-mile strip was theoretically within the realm of the Sultan's sovereignty and therefore under sharia law, all "un-owned" land along the same strip had been declared Crown land in the 1902 Crown Land Ordinance, which along with the 1908 Land Titles Ordinance served as a concessionary mechanism to encourage European plantation settlement. Furthermore, land rights grounded in sharia commonly tailed off into "customary" land practices among Swahili and Mijikenda households. ${ }^{108}$ Economic realities often determined the legal systems invoked; in

\footnotetext{
104 Memorandum of CPP to Robertson, 20 Oct. 1961, CO 894/13/2.

105 Note of meeting between Robertson and CPP delegation, Mombasa, 20 Oct. 1961, CO 894/2. Robertson deemed it impossible to expect a mwambao state to "be able to prevent infiltration and invasion by further and successive waves of up-country tribes-people in search of work, land and facilities." Moreover, "if a hostile up-country Kenya Government wished to excite agitation and disorder, the new State would not be in a position to defend itself from attack," creating a situation that would jeopardize "the safety and the peaceful development not only of the new State itself, but of the whole of East Africa." Kenya Coastal Strip, 23.

106 See Cooper, From Slaves to Squatters, ch. 5.

107 Hamidin Abd Hamid, "Unfinished Business: The Implementation of the Land Titles Ordinance in Coastal Kenya, 1908-1940s," (Ph.D. diss., University of London, 2000), 57.

108 Ibid., 47, 34-37.
} 
the plantation economies of Malindi and Takaungu, sharia and European freehold claims predominated, while less monetized districts in the north tended to be governed by customary laws. Mwambao represented a political effort not merely to protect the privileges of a certain class of landowners, but also to privilege one legal system amongst other vying contenders.

Post-war demographic and political changes strained coastal land tenure arrangements. By the 1950s, unprecedented numbers of squatters filled the lands of absentee landlords, whose main recourse for rent enforcement and removal was the colonial state. Mwambao advocates feared further encroachment by African squatters on coastal strip land, one-fifth of which had been alienated to private owners. ${ }^{109}$ By the late 1950 s, violence over the collection of rent arrears and squatter evictions had become more frequent, and certainly far more public. ${ }^{110} \mathrm{~A}$ sharp rise in world cashew nut prices in 1959 led directly to a number of violent clashes on the cashew farms of Malindi between Giriama squatters and Arab and Indian landlords, the former exercising their growing political power while the latter stubbornly refused to make formal tenancy agreements. ${ }^{111}$ Mwambao opponents feared that absentee landlords would continue removing African cultivators from their land. One school teacher wrote, "Coast Autonomy seems to be a foreign instigated move to preserve discriminatory privilages $[\mathrm{sic}]$ which we are fighting to eradicate. ... It must be very clear that the owners of these lands are not demanding independence from the British in exchange for Arab or any other imperialism." 112 Because so much Arab-owned land had remained undeveloped, mwambao supporters feared - correctly as it turned out - that an independent Kenyan government would not defend their land rights against squatters. ${ }^{113}$ Squatters continued to flock to the Protectorate, particularly Malindi, over $1960-1961 .^{114}$ The KPNP demanded that the colonial government act against squatters before its departure ${ }^{115}$ : "Many of your Highness' subjects though holding proper titles to their land find themselves faced with a serious situation because of a large number of Miji Kenda squatters who have illegally settled on their land and

109 In 1957, nearly half of the protectorate land was Crown land, a third "native land units," a fifth alienated land, and the remainder settlement and communal lands. EAC(57)3, CO $822 / 1810 / 3$.

${ }^{110}$ In one such case, a public rent strike meeting among African squatters was followed by an "assault by squatters of an Arab family following agitation to refuse to pay rent," which "caused great alarm and resulted in a deputation from local Arab landowners." Malindi Intelligence Report, Mar. 1959, KNA CB/18/18/28.

111 Malindi Intelligence Report, Dec. 1959, KNA CB/18/18/37.

112 Memorandum of Yuda Komora to Robertson, 14 Oct. 1961, CO 894/1/94.

113 Note of meeting between Robertson and Sheikh Salim Mohamed Muhashamy, Coast Liwali, 9 Oct. 1961, CO 894/2; note of meeting between Robertson and Hall, PC Coast, 21 Oct. 1961, CO $894 / 2$.

114 Jan. 1961 Report, encl. in District Officer Malindi to PC Coast, 8 Feb. 1961, KNA $\mathrm{CB} / 18 / 18 / 49$.

115 Stren, Housing the Urban Poor, 163. 
refuse to pay rent or move."116 The struggle for and against coastal sovereignty was a power contest over land, and was at its rawest in these "squatter" areas.

Deep forays into coastal history stood at the center of mwambao claims, for their legal case rested on pre-war concepts of historical sovereignty arbitrated by the few great powers. Pursuing a historical notion of sovereignty based on legal norms of nineteenth-century partition, the Coastal League declared that sovereignty could be legally acquired through settlement, conquest, or cession. Settlement on the East African coast had occurred in the decades following the advent of Islam: "Thus were formed along the Coast small states, or sultanates ... largely owing allegiance to Arabia or Persia." The coastal strip was then "re-acquired through re-conquest" after local Arabs and Omanis ousted the Portuguese by 1730 . Since the 1895 treaty showed no "cession" of sovereignty had occurred, the Coastal League concluded that separate coastal sovereignty was established in every way. ${ }^{117}$ Mwambao supporters and opponents put forward well-rehearsed if often implausible historical arguments in their fight over the turf of first-comer status and the nature of first encounters. The Central Bajun Association asserted, "We brought Islam to East Africa in 77 A.H. [696-697 C.E.], we are NOT and never have been loyal to any rule except that of the Sultan and the British."118 Other mwambao supporters grounded first-comer status on identifiable material antiquities. Shamsa Muhamad Muhashamy recalled, "We have the right to be here.... The date on our door is 275 year ago, the date of our house.... Without a doubt this is my home." "19 The Mijikenda Union, a mwambao opponent, described first encounters with Arabs as "very good" relations based on equal trade. Then, mysteriously, land alienation occurred:

We do not remember any wars between the natives and the Arabs. We do not remember any of our forefathers selling any land to the Arabs. We are surprised to see that they have now so much land hold freely. We lived on our land without any meetings (barazas) being held to discuss anything about the so-called agreement of 1895. None of our forefathers was consulted. The Kaya elders know nothing about anything that was going on between the British and the Sultan of Zanzibar. If agreement was made it was made very much behind our backs. If we had been consulted we would have bitterly rejected it as the Arabs did not at any time tell us that they had immigrated into our country to rule us.

The petition concluded, "As the Union jack leaves us so should the red flag of the Sultan.... We want peace with the Arabs so let not your decision or

\footnotetext{
116 Petition of KPNP to Sultan of Zanzibar, n.d. [c. 29 Aug. 1963], encl. in Husein to Sultan, 29 Aug. 1963, CO 822/3073/E17(iii).

117 Memorandum of Coastal League to Robertson Commission, App. C, 7 Oct. 1961, CO 894/ $12 / 6$.

118 Memorandum of Central Bajun Association [Mombasa] to Kenya Boundaries Commission, 7 Aug. 1962, CO 897/1/28.

${ }^{119}$ Mirza and Strobel, Three Swahili Women, 112.
} 
advice force us to a war with them." ${ }^{\prime 120}$ A Kwale District chief argued that since Africans were illiterate in 1895 any treaty would be non-binding. Moreover, he dismissed any Swahili claims to the coast as illegitimate, on grounds that racial impurity belied authentic autochthony: "Their mothers were African and fathers were some Arabs, some Indians including Pakistanis and others Chinese etc... Could a young 'coloured' in South Africa, for instance, who does not even know his father claim more birth right than a ZULU; or an Anglo-Indian in India more than a typical Hindu?"121 Mijikenda and other Africans regularly pointed to the questionable nature of "half-caste" birthrights of Twelve Tribe Swahili as self-evidently demonstrating their shallow roots and nullifying their "indigenous" status on the coast. ${ }^{122}$

The specter of slavery loomed large over debates about coastal history. Rumors that an independent coastal state would reintroduce slavery circulated through anti-mwambao circles. ${ }^{123}$ The KADU Mombasa branch opposed the Robertson Commission's tour plan, stating, "The majority of the present townships selected on the programme are looked upon as OLD SLAVE TRADE MARKET CENTRES where foreigners - Arabs - have established themselves under the sufferings of the Africans." "124 One well-versed African mwambao opponent reminded Britain it had allowed slavery to continue well past its takeover of the coast in 1895, "whereby hundreds of thousands of our people were enslaved for the benefit of a few score thousands of Arabs," and said he hoped Britain would not "repeat this injustice" by allowing coastal autonomy. He continued, "Though the people do not forget nor forgive, yet our people are not seeking any revenge or reparation for all the millions of our forefathers that were murdered and enslaved by the Arabs." 125 A less articulate KANU supporter declared his first reason for opposing mwambao: "I do not want Sultan Soveregnty [sic] to administer us ever, fearing Slavery Tradition."126 Such rhetoric-commonplace in Zanzibar and a rich accelerant for political violence there in the early $1960 \mathrm{~s}^{127}$ — did spark small-scale violence among various

120 Memorandum from Kilifi District [Mijikenda Union] to Robertson, 5 Oct. 1961, CO 894/14/2.

121 Memorandum of Chief Johnson Mwero of Kalaloni, Mariakani Location, Kwale District to Hull, 14 Oct. 1961, CO 894/3/6.

122 R. Mbwana Marachangoma [Digo National Union] to Robertson, 4 Oct. 1961, CO 894/12/11; Secretary, KANU Kwale Branch to Robertson, n.d. [c. Oct. 1961], CO 894/13/15; and memorandum of Wadigo (Shimba Location) to Robertson, 18 Oct. 1961, CO 894/12/59.

123 See, inter alia, CPP memorandum to Robertson, 20 Oct. 1961, CO 894/13/2.

124 J.S.J. Mambo, S.R.D. Msechu, and J. J. Mugalla [KADU Mombasa Branch] to Robertson, 9 Oct. 1961, CO 894/1/35

${ }^{125}$ Memorandum of Wanjohi wa Waciuma to Colonial Office, 24 Sept. 1961, encl. in Fry to Hull, 17 Oct. 1961, CO 894/11/3.

126 Rashid Mbwana Mwachangoma to Governor's Private Secretary, 24 Aug. 1963, CO 822/ 3073/E17(iv).

127 On rhetorical violence and racial thought in Zanzibar, see Jonathon Glassman, "Sorting Out the Tribes: The Creation of Racial Identities in Colonial Zanzibar's Newspaper Wars," Journal of African History 41 (2000): 395-428. 
political youth leagues on the coast. KANU's branch leader in Mombasa referred to Zanzibar's anti-Arab riots in June 1961 to nakedly threaten the CPP chairman with similar violence should he continue to pursue coastal autonomy. ${ }^{128}$ But the real force of political power lay far away in Nairobi. By its very provinciality, the coast was spared violence on the scale of Zanzibar. Its legal claims were too far removed, both geographically and metaphorically, from the stakes over coercive force in the new Kenyan nation.

\section{$M W A M B A O$ AFTER INDEPENDENCE}

Echoing Weber, James Sheehan argues that all sovereign claims have "a blend of legitimacy and efficacy, legality and force."129 KANU and KADU activists, otherwise bitterly divided but united in their opposition to mwambao through the voice of a generic African nationalism, easily mustered the efficacy and force necessary to convince practical British officials to abandon the awkward 1895 treaty and other legal aspects of coastal autonomy, over the objections of mwambao advocates. African nationalism, however, was a limited and most unstable political project in Kenya. Following KANU's resounding electoral victories in May 1963, KADU supporters scrambled to save regionalism (majimbo-ism) as a viable project, and even briefly supported coastal strip autonomy through its local CAPU branch, previously mwambao's most hostile opponent. Mwambao thus exited the political stage amidst scenes of desperate political opportunism by Mijikenda activists seeking any legal recourse to prevent domination by Kikuyu and Luo KANU politicians. ${ }^{130}$ Such "tribal" competition and opportunism has characterized post-colonial Kenyan politics ever since.

The bundle of claims among disaffected coastal inhabitants expressed in mwambao did not disappear after the treaty's abrogation on 8 October 1963 , Kenya's independence on 12 December 1963, or the overthrow of the Zanzibar Sultanate on 12 January 1964. At the Coastal Strip Conference held at Lancaster House in March and April 1962, Colonial Office mandarins expertly maneuvered delegates from Zanzibar and Kenya to associate with Kenya national government talks and obtained a final consensus that the Sultan would be consulted about Kenya's constitutional proposals to the extent they affected his coastal subjects. ${ }^{131}$ The Mwambao United Front (MUF), an umbrella group

\footnotetext{
128 Msanifu Kombo, Organising Secretary, KANU Mombasa Branch to Chairman, CPP, Mombasa, 3 June 1961, KNA DC/MSA/2/1/93/9/A.

129 Sheehan, "The Problem of Sovereignty," 4. Krasner similarly distinguishes authority from control. Krasner, Sovereignty, 10.

130 "Coast Region: Autonomous/Secessionist Trends," by Deputy Director of Intelligence, 25 June 1963, KNA GO/3/1/12/8. On the KANU's 1963 electoral victories, see Kyle, 171-78.

131 See minutes of F. D. Webber, 22 Mar. 1962, and W.B.L. Monson, 26 Mar. 1962, in CO 822/ 2157. Records of the four Lancaster House meetings held on 8, 9, and 12 March and 7 April 1962 are in CO 822/2159 and CAB 133/198 (National Archives, Kew).
} 
led by Abdullahi Nassir that formed after the Robertson Commission report, publicly refused to discuss "any proposals for the absorption of our territory into a Kenya under a Unitary Government" ${ }^{\prime 32}$ at Lancaster House. Two MUF delegates, Nassir and Omar Bassadiq, refused to sign the conference's published statement, reserving their position until they consulted coastal strip subjects. Upon their return they were vilified as sell-outs among mwambao supporters; such was their unpopularity that both soon quit politics and left Mombasa to pursue careers in Nairobi and Jeddah, respectively. The following year, on 8 October 1963, the coastal Protectorate was simply transferred to Kenya in an agreement between Colonial Secretary Duncan Sandys, Sultan Jamshid, Kenya Prime Minister Jomo Kenyatta, and Zanzibar Prime Minister Mohammed Shamte. This followed the signing of letters by Kenyatta and Shamte on 5 October that guaranteed five safeguards for the Sultan's subjects in the coastal strip: the free exercise and preservation of Islamic worship, the retention of kadhi jurisdiction over Muslim personal status matters, the appointment of Muslim administrators in predominantly Muslim areas, Arabic instruction for Muslim children, and the protection and continued registration of freehold land. ${ }^{133}$ Despite these safeguards, the subsequent domination of Kenya's government by upcountry Christian politicians of KANU has displaced coastal Muslims not only from local political offices (the posts of liwali and mudir were immediately abolished) but also from huge tracts of valuable rural land and urban property. ${ }^{134}$ In Kilifi District as elsewhere along the coast, political patronage has increasingly determined land access since the 1980 s, deepening the coast's squatter problem and raising broader tensions between coastal squatters and upcountry immigrants. ${ }^{135}$ Political ties within the ex-Sultanate also persevered. Mombasa was home to an informal Zanzibar "liberation committee" in the late 1970s and early 1980s as Ali Muhsin took up residence there with other ZNP exiles. Though these figures were anxious to effect change in Zanzibar, they wisely declined schemes for military intervention repeatedly offered by entrepreneurial coup-makers. ${ }^{136}$ Legal shadows of sovereignty, such as symbols of the Sultan's authority that remain in some Mombasa living rooms and popular restaurants, continue to be nurtured

\footnotetext{
132 Statement of Mwambao United Front, 17 Mar. 1962, CO 822/2158/7.

133 CO 822/3111/23-25, printed as Kenya Coastal Strip: Joint Statement, Cmnd. 1971 (London: HMSO, 1963).

134 See Thomas Wolf, “Contemporary Politics," in Jan Hoorweg et al., eds., Kenya Coast Handbook (Hamburg: Lit Verlag, 2000), 129-55; and Lisa Misol, Playing with Fire: Weapons Proliferation, Political Violence, and Human Rights in Kenya (New York: Human Rights Watch, 2002). Two of the five safeguards-provisions for Muslim Administrative Officers and Arabic education - have largely not been met since independence; the remaining three largely have.

${ }^{135}$ Karuti Kanyinga, "The Land Question in Kenya: Struggles, Accumulation and Changing Politics," (Ph.D. diss., Roskilde University, 1998), 119, 154-56.

136 Ali Muhsin al-Barwani, Conflict and Harmony, 287-88.
} 
among younger listeners of Islamic radio stations such as Radio Rahma, and among older men passing through the city's several Swahili social clubs.

Obscure details of nineteenth-century colonial treaties and alleged backroom deals struck at Lancaster House in the early 1960s still have surprising resonance in the memories of Kenyan coastal people. There is a sharp sense that the work of the Robertson Commission and its adoption by the Zanzibar Government, which led to the 1895 treaty's abrogation, was done either incompetently or in sinister invisibility. One mwambao supporter argued that it was well known that Governor Renison had traded the Sultan's coastal rights to Kenyatta in return for his promise not to expropriate white settler lands. ${ }^{137}$ In Mombasa, the specter of betrayal hangs, most unfairly, around the most important political figure of mwambao, Abdullahi Nassir. In a local radio show with Nassir, callers repeatedly asked if he had "sold" the coast during negotiations at Lancaster House; one asked if it was true that Lancaster House attendees had eaten pork, a familiar metaphor for religious betrayal. Nassir himself regards the Robertson Commission as illegitimate because it considered the opinions of those living beyond the ten-mile strip but within Coast Province. ${ }^{138}$ Debates over mwambao and the 1895 treaty continue in the Kenyan press. One intervention argued that, despite guarantees made to protect coastal institutions with the transfer of sovereignty in 1963, "provisions on Kadhis courts and the madrassas have not received the recognition they deserve." ${ }^{139}$ Mwambao claims figure in the religious-political battles over the constitutional status of Kenya's kadhi courts. ${ }^{140}$ Mombasa's mayor, Taib Ali Taib, raised the Kenyatta-Shamte agreement assuring protection of Islamic education in his criticism of the government's failure to include Islamic schools in the Ministry of Education's budget. ${ }^{141}$ Arguments are repeatedly made on the coast that Kenyan immigrants from Central Province collectively repatriate enormous sums - up to two million Kenyan shillings per annum-from their coastal enterprises. ${ }^{142}$ Feeling is widespread that the upcountry has, since independence, lived parasitically off of the coast. Hazy appropriations of mwambao have entered the bricolage of Mijikenda forest oaths that seek to remove upcountry immigrants by violence. In June 2007, police disrupted a youth military training camp of the

\footnotetext{
137 Interview with Abdalla Mbwana, Mombasa, 20 July 2006.

138 Interview with Abdullahi Nassir by Stambuli Abdillahi Nassir and Hoka wa Mwahoka entitled, "Mkataba ina Mwambao wa Pwani Mnamo 1962-1963 Lancaster House," Pwani FM (Mombasa), 8 Apr. 2004, tape recording in author's possession. On Nassir's role in mwambao, see Kai Kresse, Philosophising in Mombasa: Knowledge, Islam, and Intellectual Practice on the Swahili Coast (Edinburgh: Edinburgh University Press, 2007), 186-87.

139 Letter of Seif Mohammed Seif, Daily Nation (Nairobi), 14 Feb. 2004.

140 The Standard (Nairobi), 8 Apr. 2004. For a recent account, see Rüdiger Seesemann, "Kenyan Muslims, the Aftermath of 9/11, and the "War on Terror," in Benjamin Soares and René Otayek, eds., Islam and Muslim Politics in Africa (New York: Palgrave Macmillan, 2007), 163-68.

141 The Standard (Nairobi), 16 May 2005.

142 Mohamed Bakari and Saad Yahya, eds., Islam in Kenya (Nairobi: Mewa Publications, 1995), 238.
} 
"Republican Council of Mombasa" in Kwale District, and among the machetes and magical charms found was a book "thought to contain the history of the Kenyan coast," Nigel Pavitt's Kenya: The First Explorers. ${ }^{143}$ Given this sharp sense of coastal dispossession, memories of mwambao will likely continue to shape future claims and debates.

Unlike their Arab counterparts, most traditional sovereigns in sub-Saharan Africa failed to survive decolonization. Instead, modern nationalist parties dominated by bureaucrats established republics based on nominal popular sovereignty in most every country. The Zanzibari Sultanate was caught on this regional cusp, and bowed to African nationalist demands on coastal Kenya before being overthrown itself by these same forces in Zanzibar. Although the Sultanate of Zanzibar lacked real administrative powers, it had grown in regional significance during the years of decolonization because the Sultan's self-chosen subjects had seized upon the institution as an expression of coastal sovereignty. This "subjective" sovereignty twined together a series of legal, political, and economic claims that were collectively threatened by African nationalist projects. The mwambao movement, which had its legal basis in one British expediency — the 1895 treaty — and summoned its symbolic strength through another-flying the Sultan's flag - was undone by a final British expediency: the Robertson Commission's predetermined conclusion to unite Kenya Colony and Protectorate into a single nation-state led by electoral victors. Nonetheless, the sense of a coastal sovereignty separate from mainland Kenya has survived, and offers coastal residents an emotionally attractive if thus far impractical alternative to the ignoble patronage competitions of Kenyan national politics.

The dead ends of Africa's decolonization grow fecund as triumphalist metanarratives of nationalist victors desiccate into brittle ritual. ${ }^{144}$ Examining the subjective and contested meaning of sovereignty held by these various dead-end movements offers a fruitful way to recapture the geo-legal imaginations of historical actors confronting an international legal framework shifting from a

143 Daily Nation (Nairobi), 20 June 2007. This "council" is led by Omar Mwamndwazi and is comprised principally of young Digo men seeking to establish local land rights against "upcountry" expropriation. It springs from the "Kaya Bombo" group which - then in the name of majimboraided Likoni police station in Mombasa in August 1997, killed six police officers, and stole over forty guns. They then turned their violence to "upcountry" people and businesses, killing over a hundred and displacing some one hundred thousand people. Noel Mwakugu, "Kenya's Coastal Rebels," BBC News, 8 Apr. 2005; Amos Kareithi, "Revisiting Ten-Mile Strip Controversy," Sunday Standard (Nairobi), 30 Sept. 2007; Misol, 24-64.

144 Jean Allman, The Quills of the Porcupine: Asante Nationalism in an Emergent Ghana (Madison: University of Wisconsin Press, 1993); Luise White, The Assassination of Herbert Chitepo: Texts and Politics in Zimbabwe (Bloomington: Indiana University Press, 2003). For East Africa, see Anderson, op. cit.; Gregory Maddox and James Giblin, eds., In Search of a Nation: Histories of Authority and Dissidence in Tanzania (Oxford: James Currey, 2005); and Sauda Barwani et al., eds., Unser Leben vor der Revolution und Danach: Autobiographische Documentartexte Sansibarischer Zeitzeugen (Cologne: Köppe, 2003). 
colonial system of sovereignty based on an arbitrated recognition of sovereign figures to a post-war system of sovereignty based on territorial entitlement to selfdetermination. To understand typology-defying conceptions of sovereignty articulated by local historical actors, we must move our analytical lens freely among typologies that delineate sovereignty variously as an atomic unit of international law, a final figure of authority within a territory, and a right to external non-interference. In this way, we can shed light not only on ideational assumptions and aspirations that shaped the give-and-take of political negotiations during decolonization, but also longer-term conceptions of political legitimacy that remain, or at least try to remain, unmoved by history's sweep. 